DOI: $10.22559 /$ folklor.1025

folklor/edebiyat, cilt: 25 , sayı: 100, 2019/4

\title{
Yeni Derleme Alanları ve Dijital Ortamın Halkbilimcileri: Ekşisözlük Örneği
}

\author{
New Review Fields and the Folklorists of Digital \\ Environment: The Case of Ekşisözlük
}

\section{Azem Sevindik ${ }^{*}$ \\ Sinan Yaman ${ }^{* *}$}

\section{$\ddot{O} \mathbf{z}$}

Ses ve sözlerin sistemli bileşimlerinin, sesleri destekleyen anlamlı mimik ve tavırların, yüz yüze gerçekleştirilen iletişimin hakim olduğu sözlü kültür ortamı; sözün şekil, biçim ve yazı teknolojisiyle sözlü hafızadan yazıya kodlanmasıyla başlayan süreçte ortaya çıkan yazılı kültür ortamı (yazmalar çağı/basmalar çağı); telefon, radyo, televizyon, internet teknolojileri sonrası oluşan elektronik kültür ortamı ürünleri kültürbilimi araştırmalarında farklı metotlarla derlenmekte ve çeşitli yaklaşımlarla ele alınıp değerlendirilmektedir. Sözlü kültür ortamı, yazılı kültür ortamının aksine ifadelerin yazı teknolojisiyle kodlanmadığ damıyla taklit edilen ve hafızaya kodlanan yapılarla varlığını sürdürür. Bununla birlikte sözlü kültür ortamı folklor mahsulleri, “ikincil sözlü kültür ortamı” şeklinde tanımlanan, gösterim merkezli, yazılı icraların yanı sıra sesin ve görünün sergilendiği elektronik kültür ortamında "geleneklerin kendilerini güncelleyerek sürekliğini koruması” yasasıyla yeni yaşam alanları bulmuştur. Bu yaşam alanlarından birinin de atasözü, deyim, fikra, masal, bilmece ve türkü gibi türlerin yeni-

\footnotetext{
Dr. Öğr. Üyesi, Selçuk Üniversitesi, Edebiyat Fakültesi, Karşılaştırmalı Edebiyat Bölümü, azemsevindik@ selcuk.edu.tr. ORCID ID 0000-0001-6678-8329.

** Doktora öğrencisi, Hacettepe Üniversitesi, Sosyal Bilimler Enstitüsü, Türk Dili ve Edebiyatı Anabilim Dalı, sinanyaman@hacettepe.edu.tr. ORCID ID 0000-0002-6951-3432.
} 
den deneyimlendiği ve güncellendiği Ekşisözlük ve benzeri sanal paylaşım siteleri olduğu anlaşılmaktadır. Bu çalışmada, Ekşisözlük üzerinden her daim yeni kültür ortamlarında yaşam alanları bulmasını bilmiş olan halkbilimsel verilerin yeni derleme alanlarına, bu alanların paylaşımcılarına ve paylaşılan folklor ürünlerine dikkat çekmeyi amaçlamakta; internet ortamında paylaşılan işlev sahibi bu ürünlerle ilgili somut verileri ortaya koymak amaçlanmaktadır.

Anahtar sözcükler: halkbilimi, bağlam, derleme, dijital ortam, ekşisözlük

\begin{abstract}
The products of Oral Cultural environment, which is dominated by the systematic elements of voice and words, meaningful mimic and styles supporting voices, and face-to-face communication; the products of written cultural environment (writings age/pressing age), which emerged in the process of coding words from oral memory to writing via the technology of fonts, forms, and texts; and the products of electronic cultural environment, which have appeared after telephone, radio, television, and the internet technologies; are reviewed and investigated in cultural studies through various methods and approaches. Oral cultural environment, unlike written cultural environment, keeps its existence through the structures imitated by the specific formulas and coded into memory without coding the statements through the texting technology. In addition, the folkloric products of oral cultural environments have found new survival fields in electronic cultural environments, which are defined as "secondary oral cultural environment" and include voice and video in addition to demonstration-centered, written performance, with the law of "traditions' protection of their continuity by updating them". It is considered that Ekşisözlük and similar digital sharing sites, where such literary genres as proverbs, idioms, anecdotes, stories, riddles, and folk songs are re-experienced and re-updated, are one of those survival fields. This study aims to draw attention on the new review fields of folkloric data, which have always found new survival fields, a new cultural environment on Ekşisözlük, the sharers of these fields, and the shared folklore products. It is specifically aimed to reveal concrete information pertaining to these functional products shared on the internet.
\end{abstract}

Keywords: folklore, context, review, digital environment, ekşisözlük

\title{
Giriş
}

Alan araştırması "planlama", "derleme" ve "değerlendirme" olmak üzere üç aşamadan oluşur. Derlemeler ise "gözlem (müşahâde)" ve "görüşme (mülakat)" yoluyla derleme metotları şeklinde gerçekleştirilmektedir (Çobanoğlu, 2005: 64). Gözlem yoluyla yapılan derlemeler alan araştırmacısının icra edilecek folklor olayına aktif olarak katılımıyla gerçekleştirilen "katılımlı gözlem" ve icra edilecek folklor olayına sadece bir seyirci veya pasif bir şekilde iştirak ettiği “katılımsız gözlem” şekilde gerçekleştirilir. Görüşme yoluyla yapılan derlemeler ise derlemecinin ortaya attığ konu üzerinden kaynak kişinin tamamen serbest bir şekilde icrada bulunduğu ve bir baskı altında kalmadan kendi isteğiyle icrasını sonlandırdığı 
"yönlendirilmiş" ve derleyicinin belirli yöntemlerle özel cevaplar alabilmesi veya konunun dağılmaması için kaynak kişiyi istediği mesele üzerinde konuşturmaya yöneltmesiyle yapılan "yönlendirilmemiş" şeklinde iki farklı yöntemle yapılır (Çobanoğlu, 2005: 74-81). Yapay icra ve yaşam alanları yaratan elektronik kültür ortamında video paylaşımları, video/fotoğraf altı yorumları, sosyal paylaşım siteleri, çeşitli android programları vb. üzerinden bilimsel araştırmalara kaynaklık edecek çeşitli halkbilimi sunumları gerçekleştirilmekte, arşivlenmekte ve güncellenmektedir. Eğitimli halkbilimcilerce, klasik derleme metot ve teçhizatları kullanımına gerek kalmadan internet üzerinden gerçekleştirilecek yeni derlemelerse bir anlamda zamandan ve paradan tasarruf etme ve daha geniş kitlelere ulaşma imkânı anlamına gelmektedir. Bununla birlikte bu yeni derleme alanlarının bazı negatif yönlerinin de olduğunu söylemek gerekir. Yüz yüze iletişimin ve dekoru, ş̧ı̆̆ı̆, kokusu, zamanlaması, işlevi, kostümü, organizasyona sebep olan ayartıı içerikleri (yemek, oyun çıkarma vb.) gibi ortamın (kontext) gözleminin sınırlı bir şekilde gerçekleştirilebileceği bu derleme ortamında arzulanan hedef kitleye ulaşamama problemi de bir sorun olarak göze çarpmaktadır. Yaş, cinsiyet, meslek, şehir vb. özelliklerin nicknamelerden elde edilememesi veya video kaynaklarında kaynak kişilerle ilgili sınırlı bilgiler bulunması önemli bir sorun olarak karşımızda durmaktadır. Fakat sözlü kültür ortamı alan araştırmalarında da belirli bir meseleyi araştırmak üzere sahaya inen derlemecileri zorlayan bazı sorunların yaşandığını belirtmek gerekir. Anadolu'da pek çok kaynak kişi dijital ortama ayak uydurmada sorun yaşamakta, dijital kayıtları kaybedilecek bir mahremiyet olarak görmekte ve "internete düşme" kaygısı taşımaktadır.

Yeni bir kültürel hafiza oluşturan internet ortamında yazıll, görsel ve işitsel anlamda yeni derleme biçimleri geliştirildiği fark edilmektedir. Kendi geleneğini oluşturma sürecinde olan bu yepyeni ortamında özellikle genç kitleler tarafından çokça rağbet gören, akıllı telefonlara yüklenen programlar üzerinden vine, scorp, tik toklarda, kısa sunumların bileşimi ile oluşturulan ve belli bir saniyede ses ve görüntü birlikteliğiyle yapılan çeşitli icralar söz konusudur. İnternet katılımcılarına ustalığını kanıtlama şansı veren bu tür video paylaşım platformlarının bazı gizli işlevlerinin de (sevgili bulma gibi) olduğunu söylemek gerekir. Sanal alemde ustalıklarını göstermeye ve kendi takipçi grubunu oluşturmaya çalışan icracılar, yeteneklerini çeşitli içerikler ve konu başlıkları üzerinden kanıtlama çabasına girişmektedirler. Bu ortamlarda profesyonel olmayan ve bilimsel veriler derlemek istemeyen "amatör halkbilimciler", "küfürlü atasözleri" şeklinde bir başlık (ayak) açar. Bu "sohbet/paylaşım ayağına" ilgi duyan sanal ortam bilgeleri deneyim, tecrübe ve fikirleri ile bu yeni sanal halkbilimi grubuna katılarak icralarını gerçekleştirirler. Bu icralarsa belirli mesele ve temalar üzerinden bilimsel çalışmalar yürüten kültürbilimcilere önemli veriler sunar. Örneğin Türk eğlence kültürünün elektronik kültür ortamı boyutunu araştırmak isteyen araştırmacılar vine, scorp ve tik tok benzeri uygulamalarda şu tarz video başlıklarıyla karşılaşacaktır: "Türk olduğunu belli et", "mizahi hareketler", "iğrenç bir espri yap", "yaratıcı wi-fi şifreleri”, "küfürlü atasözleri”, "komik küfürler", "komik ayrılma bahanesi”, "çok pis laf sokma", "sen nasıl gülüyorsun", "en komik düşme hikâyen”, "sınavdayken aklımıza gelenler", "komik montaj”, "en saçma batıl inanç", "Oscarlık bir espri!", "en komik haber başlıkları", "en komik beddua", "komik 1 Nisan şakaları", "gıybet şarkısını şiveli söyle", "anne ben hamileyim ben hamileyim şakaları", "en komik alo deme şekilleri”, "duyduğun en garip isim", "komik ayrılıklar", "yanındakileri bağırarak korkut", "en komik fobin", "gülme çeşitleri”, "şive denemeleri”, "komik 
erkek mi ciddi erkek mi”, “abartılı bir haber sun”, “yanındakine sebepsizce vur”, "vizeden önce durumunuzu anlatan şarkılar", "soyadı mağdurları", "ezberlediğiniz en saçma şey", "isminizle geçilen dalgalar", "hunharca güldüren komik fotonu paylaş", "kamyoncu olsaydın kasaya ne yazardın”, "kadınlar kıraathanesi olsaydı”, "fermuarı açık kişiyi uyarmak", "semt sözleri”. Aynı şekilde Ekşisözlük’te de "askerlik” temalı çalışma yapmak isteyen bir araştırmacı çok dikkat çekici şu başlıklarla karşılaşır: “"askerden kaçarken akademik kariyer yapmak', 'askerlik erteleme yüksek lisans programı', 'askere gitmemek için kilo sınırını zorlamak', 'bedelli askerlik yapmak için araba satmak', 'bu asteğmenler de olmasa askerlik hiç çekilmez', 'askerlik muayenesinde giyilmemesi gerekenler', 'askerlik sonrası evlenme sendromu', 'askerlik yapmamak için doktora yapmak', 'askerlik bile daha iyiydi', 'bitmek bilmeyen askerlik anıları', 'kebap askerlik' (Gürel-Yakın, 2007: 215).” Ancak daha derininde bu tür paylaşımların önemsenmesi gereken bir başka yönü açılan başlıkların içeriğinde dillendirilen sözlü kültür mahsulleridir. Dedikodular yapılan, kişisel deneyim anlatıları anlatılan, sözlü ifadeye dayalı yaratıcılıkların gösterilmeye çalışılan, atasözü ve deyimlerden faydalanılan, sözlü kültür mahsullerinin gönüllü katılımlarla elde edilen icralar, "halkbiliminin elektronik kaynakları" mahiyetindedir.

Uludağ Sözlük, Kadınlar Soruyor, Ekşisözlük ve Zaytung gibi siteler, halkbilimsel verilerin derlenebileceği ve yeni türlerin doğuşunun da işaretlerinin görüldüğü diğer dijital platformlardır. Almancada "gazete" anlamına gelen zeitungdan esinlenerek isimlendirilen, sosyal ve siyasi eleştiri içerikli haberlerin verildiği elektronik gazetede (Zaytung) oyun, blog, sinema, spor, astroloji, dergi, halkın sesi, anket, store, arşiv ve haber ekle bölümlerindeki paylaşımların, yeniden birçok farklı sosyal medya sitesinde de yayıldığı/paylaşıldığı görülmektedir. Zaytung yazarlarının sosyal, siyasi ve kültürel aksaklıkları, uydurma başlıklar ve alt metinleri ile kurguladığı görülmektedir (http://www.zaytung.com).

İnternet ortamı gruplarının ne tür bir grup olduğu sorunsalı sosyal bilimi araştırmacılarının dikkatini çeken alanlardandır. Halk grupları, "aynı türden oluşan homojen gruplar, homojen olmayan gruplar, doğal gruplar, yapay gruplar, ilkel gruplar ve belirli bir yapıya sahip son derece örgütlenmiş gruplar (Freud, 2014: 28)" ş̧eklinde sınıflandırılabilseler de genel olarak doğal gruplar ve yapay gruplar başlıkları altında ele alınıp incelenebilir. Doğal grup ve yapay grup ayrımı, grup kavramını anlayabilmek için verimli bir sınıflandırma biçimi tartışmasına ön ayak olabilir. Kilise ve ordu örneklerini vererek Freud'un "bir arada bulunmak için dışarıdan bir güce ihtiyaç duyan (2014: 28)" şeklinde tanımladığı "yapay gruplar”, bu tanımın zıttı olarak gücünü bireyler üzerinden, gönüllü katılımlarla ve kendi iç dinamiğinden alan, bireylerin bazı yönleriyle kendilerini özgür hissettikleri, liderleri olmayan "doğal gruplar" esas olarak grup sınıflandırmasında iki farklı ucunu temsil eder. Freud kilise ve orduyu, bir insana danışllmaması ya da ona hiçbir seçenek verilmemesi, bu gruplardan ayrılmaya yönelik bir girişimin zulümle ve ă̆ır ceza ile karşılanması özellikleriyle yapay gruplar olarak göstermiştir. Bu iki grubun ortak paydaları komutanları ve din adamlarıdır. Bu kişiler onları bir arada tutan duygusal bağı oluşturur. Ancak Freud bu iki yapay grup arasında yapısal bazı düzenleri ve ekonomik yönleri itibariyle bir ayrıma gider (Freud, 2014: 28-29). Yüz yüze iletişimin nadiren gerçekleştirildiği, yükümlülüklerin çok sınırlı olduğu, icracılara katılımcı kitlelerin direkt olarak etki etmedikleri, uydurma bir nick ile kolaylıkla herhangi bir gruba 
dahil olunabilen ve sonrasında zaman sınırlaması olmaksızın ayrılıkların gerçekleştirilebileceği internet ortamı grupları "sanal kitleler/gruplar" şeklinde adlandırılabilirler.

Geçmişten günümüze bilindiği üzere Türk kültüründe ad almanın çeşitli biçimleri ve sosyal etkileri bulunmaktadır. Dede Korkut boylarında bazen bir çocuğun kan döküp baş kestiğinde ya da kahramanlık göstergesi bir eylemi başardığında ad aldığı görülür. Dirse Han Oğlı Buğaç Han Boyı'nun kahramanı, meydanda aşık oynarken o sırada saldıran bir boğayı alt etmesi; Kam Püre oğlu Bamsı Beyrek Boyı'nda Pay Püre'nin oğlu bezirganları gavurlardan kurtarması neticesinde Bamsı Beyrek adını alır (Ergin, 2011). Ad koyma eylemini gerçekleştiren kişi ise obanın tamam bilicisi, gaipten haber veren, boy boylayıp soy soylayan Dede Korkut'tur. Sanal ortamların bu bağlamda dikkat çekici bir yanı katılımcı kişilerin kendilerine yakıştırdıkları adları, kısa öz geçmişleri veya özelliklerinin açıklaması mahiyetindeki nicknameleri; yani elektronik kültür ortamı mahlaslarıdır. Ancak elektronik kültür ortamında ad alma süreci, biçimi ve amacının çok farklı şekilde gerçekleştirildiğini söylemek gerekir. Bu mahlasların önemli bir özelliği katılımcıların özgür iradeleriyle kendilerine yakıştırdıkları şeyler olmasıdır. Erkeklerin ve kızların yeni çeşmeleri ve buluşma alanları olan chat odalarında ve "insanların birbirlerine arkadaşlı teklifi yaptığı, arkadaşların birbirinin 'duvar'ına yazdığı, dijital ortamda birbirini dürttükleri, posta kutularına mesaj bırakıldığı ve etkinliklere katılım için davetiye gönderdiği mekânlar (Acun, 2011: 67)" olan sosyal ağlarda insanlar etkili bir izlenim yaratabilmek için büyük oranda nicklerle kendilerini ifade etmektedir. Ancak kültürel yaratmaların hemen hepsinde olduğu gibi nicklerde de eril ve dişil tutumlar söz konusudur. "Kertenkelebekir", "delidumrul", "werderveremem", "kedimi7m", "nickmickyok", "okeyin aranan dördüncüsü", "çekilinbendoktorum", "uzay diplomatı", "kertemeyen kele", "topalsolucan", "nickerim", "nicktirgit”, "internettin hoca" vb. nicklerin daha çok erkekler tarafindan karşı cinsi etkilemek ve hedef kitlenin dikkatini çekmek üzere oluşturulduğu; kadınlarınsa gerçek isim, gerçek isim ve yaş, herhangi gerçek isim, farklı bir kız ismi, isim-yaş, sıfat-isim, anlamsız harf-rakam birlikteliği ile oluşturulan nickleri kullanmayı tercih ettikleri görülmektedir.

Çeşitli konuların tartışıldığı, karşılaştırmaların yapıldığı, bilgi ve fikir alışverişinde bulunulduğu Uludăg Sözlük, Kadınlar Soruyor, Ekşisözlük vb. siteler internet ortamının yeni derleme alanları ve kaynaklarıdırlar. Bu sitelere çeşitli nicklere katılan, yorumlarını, düşüncelerini yazan pek çok kişinin özgün bir üslûp takınarak dikkat çekmeyi amaçladığı görülmektedir. Ekşisözlük'te iki çok ünlü gitar markası ile ilgili karşılaşıırmaların yapıldığı şu diyaloglar dikkat çekicidir: "Ugr Dindar: Gibson candır Fender canan; Fender ile aşk yaşanır, Gibson ile evlenilir.", "Gretsch: Şekerde Ender, gitarda Fender.", "Wywh: Fender'in logosu kendi başına bir yazı stilidir.", "Eldrun: Fender'le metal yapılmaz diyeni önce Iron Maiden sonra Malmsteen çarpar.", "Tepkili İnsan: Gibson gitarı Fender amfiye takarsanız hastalı̆̆ınız iyileşir.", "Akst: Biri pahalıdır, diğeri de pahalıdır. Fakirler için olsa olsa Epiphone vs. Squier karşılaştırması yapılabilir.", "zlatan1937: bkz.: at, avrat, Fender Strat” (https:/eksisozluk.com/fender-vs-gibson--2136114).

Sesin kullanımı ve sözün icadından sonra iletişime hâkim olan "birincil sözlü kültür ortamı (Ong, 2010: 23)"; sözün şekil, biçim ve yazı teknolojisiyle sözlü hafızadan yazıya geçilmesiyle başlayan süreçte ortaya çıkan "yazılı kültür ortamı (yazmalar çağı/basmalar çağı)"; telefon, radyo, televizyon, internet ve diğer elektronik icatlar sonrası oluşan "ikincil sözlü kültür ortamı (Ong, 2010: 24)" (elektronik kültür ortamı), kültürbilimi araştırmalarında 
ayrı ayrı ele alınıp değerlendirilmektedir. Eylemlerin, düşüncelerin, tasavvurların, hayallerin, taleplerin ve duyguların, seslerin belirli anlamlar kazanarak sistemleşmesi ile oluşan sözlü kültür ortamı "insanların yazı, matbaa ve elektronik gibi ses ve sözü mekâna bağlayan teknolojiler kullanılmaksızın, yüz yüze ve sese dayanarak iletişim kurduğu ortam (Çobanoğlu, 2000: 124)" şeklinde tanımlanmaktadır. Bireye grup kültürü oluşumunu/bilincini dayatan sözlü kültür ortamı, insanların bilinmeyen bir zamanda seslerini sistemleştirdikleri; insanların bilinmeyen bir zamandan beri seslerini çeşitli biçimlerde kullanarak isteklerini, dileklerini, tepkilerini, amaçlarını ve düşüncelerini iletişim halinde oldukları belirli bir halk grubuna ilettiği; bilgilerin, kültürün, yasaların ve inanışların belirli sözlü iletişim biçimleriyle ve kalıplarıyla öğretilip aktarıldığı; sesin şiddetiyle ve kullanım biçimleriyle mevcut halk grubunda çeşitli şekillerde anlamlandırıldığı kültür evresidir.

Sözlü ve yazılı kültür ortamı arasındaki ayrım ancak elektronik çağda kavranabilmiştir. Çünkü, elektronik iletişim araçlarıyla matbaa arasında var olan bazı farklılıkların sezilmesi sözlü kültür ortamı ve elektronik kültür ortamı arasındaki farklılıkların fark edilebilmesine de sebep olmuştur (Ong, 2010: 15).” Jack Goody'nin The Domestication of Savage Mind (Yabanıl Aklın Evcilleştirilmesi) ve Literacy in Traditional Societies (Gelenekçi Toplumlarda Okuryazarlık) çalışmalarında düşünsel ve toplumsal yapıların yazı sonrası yaşadıkları farklılıklar ve değişimler ele alınıp değerlendirilmiştir (Ong, 2010: 18). Yine Goody "Sözlü Kültür" makalesinde sözlü kültür ve diğer kültür ortamları arasındaki farklılıkların değerlendirildiği karşılaştırmalı çalışmalara göndermeler yaparak bazı yaklaşım eksiklik ve yanlışlıklarına değinmiş; iletişim kurmanın sadece başka yolu olan yazılı ve elektronik kültür ortamının hiçbir şekilde sözlü iletişimin yerine geçemeyeceğini savunmuştur. Yazı sahibi toplumlarla yazı sahibi olmayan toplumlar arasındaki sözlü iletişim de aynı değildir. Yazılı kültürün olmadığı sözlü kültür toplumlarında sözlü gelenek, kültürel aktarımın bütün yükünü taşımak zorundadır. Bir başka ayrılık ise yazılı geleneğe mensup olanların sözlü biçimleri anlaması ve algilamasında yatar (2009: 128).

Sosyokültürel ortamın yaşam alışkanlıkları durmadan değişmekte ve insan da bu değişimin önemli bir aktörü olarak sahne almaktadır. Bununla birlikte değişen ortamlara, kabullere ve değer yargılarına bağlı olarak halkbilimi yaratmaları da sürekli güncellenmektedir. Bu refleks, türlerin geleceğe kendilerini taşımaları için son derece hayatidir. Hemen her kültürel ortama ayak uyduran folklor; yaratmaları, icraları, icracıları, kitlesi ve tüketimi ile "ikincil sözlü kültür" olarak da adlandırılan bu yepyeni ortama da bir şeklide uyum sağlamasını bilmiştir. Bu yeni ortam "varlığı yazı ve matbaa teknolojilerine dayanan telefon, radyo ve televizyona özgü sözlü kültür çağıdır (Ong, 2010: 15)”. Aslında bu değişen, dönüşen, farklılaşan, farklı işlevler kazanan folklorun güncel durumu, yaşama ve kendini ifade etme biçimi Benjamin A. Botkin'in ifadesiyle "yeni şişelerde eski şarap ve aynı zamanda eski şişelerde taze şarap (akt. Oğuz vd. 2014: 29)" şeklinde özetlenebilir. Kimi zaman "eski şarap" olan folklor ürünleri yeni bir şişede (elektronik kültür ortamında) boy göstermekte; bazen de yeni şişelerde üretilen güncellenmiş folklor mahsulleri olarak eski şişelerde (sözlü kültür ortamlarında) tekrardan belirebilmektedir. Bu dönüşüm süreci yok olmamak için kendisini güncelleme reflekslerine erişebilmiş bazı halkbilimi geleneklerinin tabiatının gereğidir. 


\section{Ekşisözlük nedir?}

"Ekşisözlük, her türlü kavram ve kelime hakkında kayıtlı yazarların yorumlarını içeren ve katılımcı sözlük -collaborative hypertext dictionary- özelliği olan bir web sitesidir. Ssg rumuzu -nickname- ile tanınan Sedat Kasapoğlu tarafından 1999 tarihinde yaratılmıştır (Gürel-Yakın, 2007: 204).” Araştırmada örnek olarak seçilen Ekşisözlük'te sözlük kullanıcılarının kendilerini ayrı ve özgün bir halk grubu şeklinde değerlendirdiği, paylaşımlarda sözlü türlerle ilgili örnekler verildiği, bilimsel alıntılamaların kullanıldığı, şaşırtıcı tanımlamaların yapıldığı, yeni güncellemelerin oluşturulduğu, türlerin çeşitli özelliklerine göre isimlendirildiği fark edilmektedir. Sözlükte hiyerarşik bir düzenin de oluşturulduğu anlaşılmaktadır. $\mathrm{Bu}$ anlamda "ssg rumuzu ile tanınan Sözlük'ün kurucusu ve kural koyucusunun yanı sıra Sözlük'ün şekillenmesinde ve faaliyet göstermesinde aktif bir rol üstlenen 'moderatör', 'gammaz', 'praetör', 'çaylak yazar', 'sürekli yazar' ve 'yazar' statüleri kapsamında gruplanan (Gürel-Yakın, 2007: 206)” kullanıcıların yetki alanları da söz konusudur. Belirli kurallar, gelenekler ve ortak paydalar dahilinde katılımcıların tasarımlarını ve fikirlerini ifade ettikleri bu ve benzeri sanal ortamlar, halkbilimcilere yeni araştırma alanları ve kolaylıkları sağlamaktadır. Derlenecek malzeme seçilecek herhangi bir konu külfetinde ve bir bilgisayar uzaklığındadır. Çalışma, bazı halkbilimi anlatmaya/söylemeye dayalı (sözlü) türler üzerine açılan, her biri ayrı bir makale konusu olabilecek başlıklar ve başlıklar içerisinde verilen bazı örneklerle sınırlı tutulacak; halkbilimsel verilerin anlaşılabilmesi için atasözü ve deyimler üzerine açılmış başlıklar içerisindeki paylaşımlardan örnekler verilecektir.

\section{Ekşisözlük'te atasözü}

Sözlü yapıları, toplumsal anlamı (Başgöz, 2006: 85-91), oluşum ve gelişim evrelerinin bilinmezliği gibi özelliklere sahip olan atasözleri hemen her milletin sözlü yaratmalarında karşımıza çıkar. Atasözlerinin yer, zaman ve mekân bakımından kesin hükümlerle tespitinin mümkün olmadığını belirten Çobanoğlu, atasözlerinin muhtemelen ulusların daha henüz küçük topluluklar halindeki öncü nüvelerinin, kendileri içerisinde yalnız ve diğer canlılara göre oldukça çaresiz buldukları tabiatta, bitki kökleri ve meyveleri devşirerek hayatta kaldıkları toplayıcılık dönemlerinden veya dilin ortak bir anlaşma sistemi haline gelmesinden itibaren, yani insanlık tarihinin bilinmeyen en erken çağlarından beri var olduğunu belirtir (2004: 1-2). Bilgi verici özellikleriyle toplumlara nasihatler veren, onları yönlendiren, uyaran ve ikaz eden atasözleri, özlü sözel bilgi küpleridir. Walter Ong’un söylemi ve düşünceyi sözel kalıpların oluşturduğunu savunup bu kalıpları bilgi depolama ve aktarma aracı ve bir anlamda formülü olarak gördüğü atasözleri, toplumsal hafızaya bağımlı olarak yeri geldiğinde açılır ve kullanılır (akt. Özdemir, 2008a: 151). Atasözleri, sıkıştırılıp teksif edilmiş duygu ve düşünceleri itibariyle, adeta konserve halindeki bilgilerdir. Onlar ilkel toplulukları da içine alır bir şekilde, toplum hayatı içerisinde yaşayan bireyin, okulu, yeryüzünde yaşama kılavuzu veya el kitabı niteliğindeki sosyokültürel düsturlardır (Çobanoğlu, 2004: 2).

Atasözlerinin internet ortamında yeniden ele alındığı, değiştirildiği ve dönüştürüldüğü görülmektedir. Selcan Gürçayır "Kuşaktan Foruma Geçiş ve Bilgisayar Atasözleri” (2008) adlı makalesinde, sözlü kültür ortamında yaşayan asıl atasözlerinin birtakım değişiklikler ile sanal dünyaya yeniden uyarlanmalarını, bu hikmetli sözlerin doğruluklarının sanal ortamda yeniden 
onaylanması olarak görür. Bu anlamda sanal ortamda birçok atasözünün "Hack'e giden hacklenir", "Bana dokunmayan worm bin yıl yaşasın", "Beleş anti-virüs programı; virüsü türkü çağıra çağıra ararmış”, "Sakla set-up'ı gelir zamanı”, "Orijinal program kullananı dokuz ağdan kovarlar", "Windows'a service pack de yüklesen, windows yine windowstur”, "Bugünün işini görev zamanlayıcısına bırakma", "Ağ alma komşu al”, "Virüsünü söylemeyen anti-virüsünü bulamaz", "Virüs geliyorum demez", "Virüsle yatan program kopyasıyla kalkar”, "Virüsün baş1 küçükken ezilir", "Virüs istedi bir exe, Allah verdi iki exe”, "Tuşa basmakla klavye eskimez", "Virüs ölür gözü diskette kalır", "Yol sormakla, keyword aramakla bulunur", "Yazıcının şahidi tarayıcı", "Dos kocamış; windowsun maskarası olmuş", "Ak anti-virüs kara gün içindir", "Resette keramet vardır", "Çökecek windows bilgisayarda durmaz", "Sabrın sonu resettir" ve "Virüsü an, anti-virüsü hazırla" (Gürçayır, 2008: 77) şeklinde yeniden uyarlandığı görülür. Bu bağlamda atasözlerinin paylaşıldığı ve yeniden güncellendiği Ekşisözlük’te şu dikkat çekici başlıkların açıldığı görülmektedir: sözlük yazarlarının favori atasözleri (dişi albatros: kabahat altın olsa kimse sahiplenmez/ bodenstraubsauger: koyunun olmadığ1 yerde keçiye Abdurrahman Çelebi derler/ domatescorbası: ..tüyle inatlaşan donuna ..çar vb.), süper atasözleri (loop: sen ağa, ben ağa, bu ineği kim sağa/ otisabi: esmere el bağla, karşısına geç ağla/ castro: hacı hacıyı tekkede, hoca hocayı tekkede, deli deliyi dakkada bulur), atasözü (loosey: küçükken, birtakım yaşlı adamların kocaman bir odada toplanaraktan birbirlerine söyledikleri sözlerden oluştuğunu sandığım özlü ukalalıklar/ akhilleus: ataların başarısızlıklarından ve bol bol yapmış oldukları hatalardan türettikleri yoğunlaştırılmış sözcük öbekleri/ kaktus: mutlaka bir yargı içerir ve daima önerme formundadır vb.), yaran atasözleri (issue: kelin yanında kabak anılmaz/ dubur: hem yoksul hem de ...i büyük/ kasaturasız rambo: kafirden hacı, elden bacı olmaz vb.), ilginç atasözleri (senedebirgün: yazın gölge kovan, zemheride karnın ovar/ ecelsiz: gamsız öküz kasabın bıçağını yalar vb.), alternatif atasözleri (carpenoctem: ak akbil kara gün içindir/ renovation: ayinesi entrydir kişinin, nesile bakılmaz/ desmont: seçilmiş cumhurbaşkanının davası olmaz; bkz. Uğur Mumcu/ ucan adam: tencere yuvarlanmış bir Çinliye isim olmuş; teng tung cheng fong/ herşey yanlış: körle yatan saçı başı dağınık kalkar/ gökkuşağı: eve kız atan kılıfını hazırlar; bana Facebook’unu ver sana kim olduğunu söyleyeyim vb.), küfürlü atasözü ve deyimler (valost: ...e giren şemsiye açılmaz/ spinabubica: elin ...ini görmeyen kendi ...ini piyade tüfeği sanırmış vb.), Çin atasözleri (yeti: çizmedin ki kesesing/ siyah martı: kurbağa her zaman kurbağadır/ novaa: zeki insanların iradeleri, zayıf insanların ümitleri vardır vb.), Türk atasözleri (frombillericay: laf lafı açar, laf ...ü açar; kasnak yuvarlandı elek oldu, eski ....pular melek oldu vb.), erotik içerikli atasözü ve deyimler (marya peru: delikli boncuk yerde kalmaz/ uysalpsikopat: ...puyu mezara koymuşlar, tek mi yatacağım demiş vb.), saçma sapan atasözleri (barbar: atılan her iftiranın süper etkili olmasını sağlamaktan başka bir işe yaramayan atasözümüz; ateş olmayan yerden duman çıkmaz/ lollabits: tecrübeyle ne sabittir ki bu sabit olsun; acemi çavuşlar, döner kıçını avuçlar/ yalnıztroll: az veren candır, çok veren maldır vb.), modern atasözleri (yazdur: bir kızı bir milyon kişi takip eder, bir kişi alır/ vitali daraselia: Youtube'a düşmüş tapenin davası olmaz vb.), sözlük atasözleri (iron: edit girmeyen entrye moderatör girer/ zzg besa: entry editle sıvanmaz/ silgisayar: yazar yazara baka baka yazar/ godot: biri yazar biri bakar k1yamet ondan kopar vb.), Ingilizce atasözleri (huger: if the shoe fits, weat it; yarası olan gocunur-love endures all thinks; gülü seven dikenine katlanır/ koit: life happens; her şey olacağına varır vb.), Latin atasözleri (vakai vakvakiye: fiat justitia, pereat mundus; 
dünya yıkılsa da bırak adalet yerini bulsun/ theory of everything: omnia vincit amor; aşk her şeyi yener vb.), ırkçı atasözleri (kavaklıdereankara: ne deyim Allah'a, don giydirdi Fellah'a/ aşk ve obur cinler: ne Şam'ın şekeri ne Arab'ın yüzü vb.), Afrika atasözleri (tabularasa: filden büyük bir şey varsa o da ormandır/ skur: ok atanın, taş bileyenindir/ olympos: kertenkeleden korkan iguananın çocuğu olmaz vb.), tiki atasözleri (changes: otobüse binme oha falan olursun/ red g: markanı söyle, sana arkadaşını söyleyeyim; solaryum girmeyen eve doktor girer/ biteker: club'e giren terler/ whiteshadow: Porsche'nin nesi var, Ferrari'nin sesi var/ anti: marka giymeyeni dokuz clup'tan kovarlar/ bushwacker: çirkin fotoğraf yoktur, az fotoshop vardır/ antionary: kal geliyorum demez/ era esto: arabası olmayan çocuğa meme vermezler/ beşinci göz: oha falan olunmaz, oha falan doğulur/ dare: tikinin dostu olmaz vb.), yazarları en çok tecrübe ettiği atasözleri (bir uzay maymunu: öfkeyle kalkan zararla oturur vb.), müstehcen atasözleri (vimifer: ....pu tövbe tutmaz vb.), yanlış anlaşılmış atasözleri (neredenbileyimben: azimli sıçan/fare taşı deler/ orijinalden alıntı: eşek hoş laftan ne anlar vb.), müzisyen atasözleri (samuel: parça arasında çalınmaz/ jeanluc: en iyi orkestra şefi ölü olandır/ yaşanan kaygı: la minörü olanın dini olmaz/ cannibal: sucukta ender gitarda fender), ilginç atasözleri (nyks: ununu elemiş eleğini asmış/ pillibebek: tavşan dağa küsmüş dağın haberi olmamış vb.), Türk halkının ăgzına ...mış atasözleri (odhner: bana dokunmayan yılan bin yaşasın; baldız baldan tatlıdır/ ağabey: kervan yolda düzülür vb.), sonradan anlaşılan atasözleri ve deyimler (marmara66: işten artırılmaz dişten artırılır/ sadisirazi: acıma yetime, döner koyar ...üne vb.), coder atasözleri (ssg: syntax error yiğidin kamçısıdır/ barbie: her errorda bir getlasterror vardır/ cyrus: kodunu yazan programını derler/ abani: hatasız kod yoktur/ overflow: akılsız coder'in zahmetini cpu çeker/ tolginho: akılsız başın cezasını parmaklar çeker; bir resetin bin hikâyesi vardır vb.).

\section{Ekşisözlük’te deyim}

Sözlü yaratmaların bir başka önemli türü olan deyimler "genellikle gerçek anlamından az çok ayrı, kendine özgü bir anlam taşıyan kalıplaşmış söz öbeği, tabir (http://www.tdk.gov.tr)” şeklinde tanımlanmaktadır. İçerisinde birçok anlam sanatını barındıran deyimlerin Göktürk yazıtlarına kadar uzanan somut verileri söz konusudur: "Uçup gitmek”, "adı sanı yok olmak", "kökünü kurutmak" (Ergin, 1992). Anlatımı daha akıcı kılmak için taşlara kodlanan işlev sahibi bu söz öbeklerinin dijital ortamda tanımlandığı, kategorize edildiği ve anlamı üzerine özgün fikirler beyan edildiği görülmektedir. Ekşisözlük’te açılan deyim başlıkları içerisine kullanıcılarca dikkat çekici çeşitli paylaşımların yapıldığı göze çarpmaktadır: deyim (felis: bkz. tabir/ chosen: bkz. söz, terim/ andrew: mecazi kalıplaşmış anlatımlar vb.), yaran deyimler (kadimokul: dibek taşı gibi oturmak/ nerdeyim ben: kıçıyla dünyayı devirmek/ rakı balık Ayvalık: kestaneyi çizdirmek vb.), ekşideyim (risk: bir ayağı çukurda olmak; gözden düşmek vb.), en abuk deyimler (nevermind: burnunda tütmek; kanına ekmek doğramak/ geyique: külahları değişmek/ stankfinds: besmele görmüş şeytan gibi olmak/ pathetique: it ayağ1 yemiş gibi gezmek vb.), deyimler sözlüğü (bika: sayfa sayısı nedeniyle içinde milyon tane deyim barındırdığını düşündüren, fakat buna rağmen ..te gelmek, eline vermek, akıl almak gibi çok kullanılan deyimlerin içinde hiç geçmediği sözlük), ilginç deyimler (iskra: her rengi boyadık, fıstığın yeşili kaldı/ bir filozof üret: cemaziyü'l-evvelini bilmek vb.), dededen duyulan deyimler (emprikles: İngiliz kaşığıyla Fransız ...u yemek/ kerdi: kaderiyle küllenmek vb.), yöresel deyimler (emmoglu: yü- 
reği hırp etmek/ brugge 1907: at alıp eşşek satmak/ banasorsevgilikarı: yivindiz olmak; bir anda ortadan kaybolmak, sıvışmak vb.), çelişkili atasözleri ve deyimler (pacifia: bir elin nesi var, iki elin sesi var-nerde çokluk orda ...luk/ motorla odun kesilir: damlaya damlaya göl olur-taşıma su ile değirmen dönmez/ mir: azıcık aşım ağrımaz başım-fazla mal göz çıkarmaz/ unlem: iyilik yapan iyilik bulur-iyiliğe iyilik olsaydı koca öküze bıçak çalınmazdı/ somebodytolove: iyi insan lafin üstüne gelirmiş-iti an çomağı hazırla/ kivircik: erken kalkan yol alır-acele işe şeytan karışır/ cornavin: zararın neresinden dönersen kârdır-battı balık yan gider vb.), küfürlü deyimler (cyric: iki eliyle bir ..ki doğrultamamak/ profexor: it ...rdukça yalan söylemek/ arbuk: ..tü baş1 dağıtmak vb.), 3000 yllında söylenecek deyimler ve atasözleri (sophieinbox: Facebook'u olma-

yanın dostu, dostu olmayanın İnstagramı olmazmış/ arizona kertenkelesi: ışın kılıcı kınından çıktığı zaman, tüm androidler dağılır vb.), faşist deyimler (fair: E.... gelini gibi kıvırtmak vb.), Almanca deyimler (rosa regenmantel: bir konuyu abartmamak anlamında 'dir kirche im dorf lassen'; kiliseyi köyde bırakmak/ feliade: bir konuyu ifşa etmek anlamında 'die hose runterlassen'; pantolonu indirmek/ prince: ‘öl ins feuer gießen'; yangına körükle gitmek vb.), yanlış kullanılan deyimler (ever the moon: yanlış; içten bile değil-doğru; işten bile değil/ astacadell: yanlış; mezhebi geniş olmak-meşrebi geniş olmak vb.), deyim öyküleri (nervusvagus: dolap çevirmek hakkında.../ yamanh: ateş pahası olmak hakkında... vb.).

\section{Ekşisözlük’te ninni}

Ninniler bilinen en eski sözlü kültür ürünlerindendir (Uğurlu, 2014: 44) ve içeriklerinde pek çok sosyokültürel konuyu barındıran bir yapıya sahiptir. Ninniler, bebeklerin dikkatinin sıralı, uyumlu ve büyüsel sözcüklerle uyuşturmasına sebep olur. Benlik böylece dikte edilen meselelere açık hale gelir. Ninniler vasıtasıyla “doğum, sünnet, askerlik, düğün, ölümle ilgili anlayış ve uygulamalar; meslek tercihi, yemek, giyim kuşam, ev bark düzeni (Uğurlu, 2014: 43)" gibi meseleler toplumsal bağlama yeni katılan bebeğe aktarılmakta ve böylece bebekler mensubu oldukları sosyokültürel ortamın tüm kodlarını ilk olarak ninnilerin dilinden öğrenmeye başlamaktadırlar. İlk eğitim ve öğrenme yöntemleri olan ninnilerle bebekler toplumsal dili, müzikal tınıları ve hatta bunların gösterim biçimlerini öğrendiklerler. Ekşisözlük’te ise ninni temalı şu başlıklar açıldığı tespit edilmiştir:

en güzel ninniler, ninni, bizim ninniler, Anadolu ninnileri, ninniler ve ensest psikodinamikleri, annelerin uydurduğu ninniler, alternatif ninniler, ninni çocuğum ninni, kullanıcı: ninni, ninni gibi şarkılar, ser ekseninde ninniler, TRT Çocuk bizim ninniler animasyonu, uyusun da büyüsün, Oğuz Atay Tutunamayanlar kitabında ninni, acı ninni, güle ninni, Elif'e ninni, saat alarmı olarak ninni, anneye ninni, ulusun da büyüsün ninni.

\section{Ekşisözlük'te masal}

William R. Bascom'un mit ve efsanelerle karşılaştırdığı tablosunda masalların özelliklerini inanma açısından "kurmaca", zaman açısından "herhangi bir zaman dilimi", yer açısından "herhangi bir yer", kabul ediş tavrı açısından "kutsal olmayan" ve temel karakterler açısından "insan veya diğer" şeklinde vermiş (Oğuz vd., 2005: 117) ve Boratav bu tabloya da uygun olarak masalları, "nesirle söylenmiş, dinlik ve büyülük inanışlardan ve törenlerden 
bağımsız, tamamıyla hayâl ürünü, gerçeklerle ilgisiz ve anlattıklarına inandırmak iddiası olmayan kısa bir anlatı (2015: 85)" şeklinde tanımlamıştır.

İnsanoğlu her daim gizemleri ve kurguları arzular veya bunlara ihtiyaç duyar. Modern çağın teknolojik imkanları ise insanoğlunun alışkanlıklarına yön verse de insancıl kodların tamamıyla değişmesini başaracak güçte değildir. Mekanlar değişse de insanlar televizyon dizilerinde olağanüstü aşkları, Keloğlan masallarını ve çeşitli filmlerde geleneksel Türk tiyatrosu tiplerini/imgelerini büyük bir hayranlıkla izlemekte, sanal alemde fikraları dillendirmekte, radyolarda kişisel deneyim anlatılarını dinlemekte, gazete başlıklarında kullanılan atasözü ve deyimleri beğeniyle okumakta; talk şovlarda meddah, radyolarda laf ebeleri, Vine, Scorp ve Tik Toklarda usta icracı olma arzusundan kendilerini alamamaktadır. Tüm bunlarla birlikte sözlü türlerin dijital ürün içeriklerinde kültürel ekonomik bir enstrüman olarak kullanıldığı görülmektedir. Akıllı cep telefonu uygulamalarında halkbilimsel ve daha genel olarak kültürel ürünlerin elektronik satışı gerçekleşmektedir. Türkü, masal, ninni, tekerleme, fikra vb. uygulamaları dijital sektörün yeni kültürel ekonomik kaynaklarıdırlar. Bu anlamda Masalcı, Masalım, Harika Peri Masalları, Resimli Masallar, Sesli Masallar, Masal Zamanı, Kitap ve Boyama Masalları, Prenses Masallar Boyama Kitabı, Masal Dinle, Keloğlan: Çocuk Kitabı ve Oyunları, Çocuklar Iç̧in Masallar, Masalcı Teyze, Keloğlan Sesli Masalları vb. masal uygulamaları halkbilimi unsurlarının dijital pazarlamada kültürel ekonomik bir unsur olarak boy gösterdiğinin kanıtı olmalıdır. Masalların boy gösterdiği alanlardan biri de sosyalleşme, bilgi paylaşımı ve fikir alışverişi imkânı tanıtan “dijital sözlük”lerdir. Bu dijital sözlüklerden biri olan Ekşisözlük’te masallarla ilgili şu başlıkların açıldı̆̆ı tespit edilmiştir:

masal, sözlük yazarlarından masallar, dünyanın en güzel masalları, modern masallar, La Fontaine'den masallar, altın masallar, renkli masallar, ne olur gerçek olsa masallar, sözlük yazarlarının çocukken en sevdiği masallar, ekşi masal, masallar, masal okumak, masal dinlemek, masal kitabı, alo masal, her güne bir masal, masal dinlemeyi özlemek, çocuklara masallar, inandı̆̆ım masallar, uyuması için çocuğa masal okumak, masala, masal ve animasyonlarda mutlak mutlu son takıntısı, ama masal aleminde de yaşamıyoruz, masal gibi, karşı masal, tehlikeli masal, mitolojiden masallar, Ezop'tan masallar, emprovize masallar, masallar ve toplumsal cinsiyet, travmatik masallar, uykusuza masallar.

\section{Ekșisözlük’te fikra}

F1kra, Türk Ansiklopedisi'nde tanınmış bir şahsiyetin özlü bir sözünü, nükteli bir cevabını, hoş bir tepkisini ilgili tarih olgusu içinde toplayan gerçek veya gerçeğe yakın bir hikâyecik; Hâmit Zübeyr Koşay tarafından "şahısların, devrin ve fikri cereyanların karakterini canlandıran hâdiselerin dikkate değer olması"; Sabri Esat Siyavuşgil tarafından "beşerî kusurlarla içtimai çarpıklıkların keskin bir sağduyu ile yapılmış parlak hicivleri” şeklinde tanımlanmıştır (Yıldırım, 2016: 34-35). Türk halkının ince zekâsının da sözlü imzaları olan Türk fikraları Selçuklu mizahının önemli bir unsuru olan Nasreddin Hoca, Osmanlı mizahının önemli tipleri olan Bektaşi, İncili Çavuş üzerinden yaygın olarak üretilirler. Bu üretim süreci internet ortamında da sürmektedir. Nebi Özdemir "Kültürel Ekonomik İmge Olarak Nasreddin Hoca" adlı makalesinde "sözlü kültürde yaratılmakla birlikte, yazılı kültürde yaşatılmış, bugün de sanal/dijital kültürde” yaşatılmakta olan Nasreddin Hoca'nın "hackleyen, 
disketi bardak altlığı olarak kullanan, MSN'de gevezelik eden, sörf yapan” biri olarak yeniden güncellendiğine dikkat çekmektedir (2008b: 11-20). Bu özlü ifade biçimlerinin çağa, çağın ürünlerine ve koşullarına uygun olarak dijital ortamda yeniden güncellendiği görülmektedir. Ekşisözlük’te ise fikralarla ilgili şu başlıkların açıldığı görülmektedir:

fikra, yaran fikralar, dünyanin en komik fikrası, en kısa fikralar, temel fikraları, yarmayan fikralar, saçma fikralar, fikra anlatmak, sözlükte fikra anlatmak, bugünleri anlatan en iyi fikralar, günümüzü anlatan fikralar, Türkiye'yi en iyi anlatan fikra, Nasreddin Hoca, Nasreddin Hoca fikralarl, alternatif Nasreddin Hoca fikralarl, emprovize Nasreddin Hoca fikraları, dövme yaptırllası Nasreddin Hoca fikraları, Bektaşi, Bektaşi fikraları, Incili Çavuş, Temel fikraları.

\section{Ekşisözlük'te tekerleme}

Benzetmeler ve ses oyunları kullanılarak oluşturulan tekerlemeler gerek çocukların gerekse büyüklerin çocukları eğlendirmek için birbirleriyle ilgili ya da ilgisiz düşüncelerin durumların adı ardına belirli bir tempoda söylenmesi ile oluşturulan, gülmeyi, güldürmeyi ve eğlenmeyi amaçlan metinlerdir. İşlevsel bir sözlü tür olan tekerlemeler pek çok türün içerisinde etkin bir biçimde belirir.

Tekerlemeleri "masal tekerlemeleri, oyun tekerlemeleri, tören tekerlemeleri, bağımsız söz cambazlığı değerinde tekerlemeler" şeklinde gruplandıran ve bu türün türkü, âşık tarzı yaratmalar, masal, oyun, hikâye, Karagöz ve orta oyunu gibi diğer türlerle ilişki içerisinde olduğunu belirten Boratav, tekerlemelerin özelliklerini; herhangi bir ana konudan yoksun, başuyaklar ve uyaklarla elde edilen ses oyunları ile ve çağrışımlarla birbirine bağlanan, belirli bir şiir düzenine uydurulan, birbirini tutmaz birtakım hayâl ve düşüncelerin sıralandığı, mantık dışı bir takım sonuçlara varmakla şaşırtıcı bir etki yaratan, şaşırtmak, eğlendirmek, keyiflendirmek için başvurulan bir söz cambazlığg şeklinde sıralamıştır (2015: 155-156). Ekşisözlük’te tekerlemelerle ilgili şu başlıkların açıldığı görülmektedir:

tekerleme, en süper ve en eski tekerlemeler, saçma salak çocuk tekerlemeleri, Ankara tekerlemeleri, Ingilizce tekerlemeler, çocukken söylenen manasız tekerlemeler, tekerleme ve benzeri, en süper ve en seksi tekerlemeler, çocuk oyunlarında tekerlemeler, Italyanca tekerlemeler, çocukken söylenen küfürlü tekerlemeler, ırkçı tekerlemeler, açık saçık tekerlemeler, Türkçedeki en uzun tekerlemeler, disiplin tekerlemeleri, söylenişi zor tekerlemeler, developer tekerlemeleri, isimler ardindan yapılan tekerlemeler, Ingilizce ögrenirken ezberlenen tekerlemeler, Almanca ögrenme amaçl tekerlemeler, Fransızca ögrenme amaçlı tekerlemeler, asker tekerlemeleri, bilişim tekerlemeleri, ekmeleddin tekerlemeleri, alternatif bir berber bir berbere tekerlemeleri, dil dügümleyen tekerlemeler, ayll tekerlemeler.

\section{Ekşisözlük’te bilmece}

Aristoteles Poetica'sında açık, yavan ve ağırbaşlı dil karşılaştırmalarını yaptığı ve belki de ilk olarak standart dilin sınırlarının çizildiği dilin kullanımıyla ilgili bölümde metafor ve bilmece ilişkisini açıkça ortaya koymuştur. Aristoteles'e göre bilmecelerin biçimi, gerçek şeylerden söz ederken olanaksız şeyleri bir araya getirilmesiyle, yani metaforların kullanı- 
mıyla oluşur (2017: 65). Bununla birlikte "Kafa karışıklığı yaratmak veya cevabı bilmeyen kişilerin nüktedanlığını denemek amacıyla oluşturulmuş sorular (Abraham-Dundes, 2007: 118)" olan bilmeceler rakibi alt etme üzerine kurulu olan, tarafların birbirlerini test ettikleri, bilgilerini ve akıllarını sınadıkları, atışma havasında geçen ve ip uçlarıyla zihinlerde çağrışımlar yaratan halkbilimi ürünleridir.

Eğlenceli içerikleri bünyesinde barındıran bilmecelerin internet ortamında, radyo sohbetlerinde, yarışma programlarında, çocuk TV kanallarında, dizilerde ve filmlerde kullanıldığı fark edilmektedir. Sözlü kültürden edebiyat mahsullerine, oradan da çok yüksek bütçeli bir film yapımına taşınan bilmecelerin internet ortamında da çeşitli işlevleriyle boy gösterdiği fark edilmektedir. Bu anlamda Ekşisözlük’te bilmeceler üzerine şu başlıklar açılmıştır:

bilmece, iğrenç bilmeceler, ilkokul bilmeceleri, yaran bilmeceler, sözlük bilmeceleri, matematik temelli bilmeceler, ekşi bilmece, cevabı ayı bir şey sanılan bilmece, zipır bilmeceler, ilkokulda bilmece soran çocuk, beyin yakan bilmeceler, karanlıkta bilmeceler, çözülmeyi bekleyen bilmeceler, süper bilmeceler, bilmece muhaveresi, bilmece ve bulmaca, bilmece gibi konuşmak, bilmece formatında başlık açmak, bilimsel bilmece, gündelik bilmeceler, bilmeceler kehanetler, erotik bilmeceler, güldüren soğuk bilmeceler, bir bilmecem var.

\section{Ekșisözlük'te mâni}

Amacı itibariyle sistemli bir şekilde üstün gelmeyi, alt etmeyi ve dolayısıyla gülmeyi/ güldürmeyi hedefleyen maniler, yapıları itibariyle Nevzat Gözaydın tarafından "bir tek dörtlük içinde bir anlam bütünlüğü göstermek zorunda olan, ilk iki dize, asıl anlamı veren son dizelere bir hazırlık yapılmasını sağlayan doldurma dizeleri olan ve genelde yedi heceli ve dört dizeden oluşan, a a x a biçiminde uyaklanan bir nazım şekli (Oğuz vd., 2005: 267)" olarak tanımlanmıştır. Maniler, Boratav tarafından söylenme yerleri ve şartları dikkate alınarak “1. Niyet, fal (yorum) manileri, 2. Sevda mânileri, 3. İş mânileri, 4. Bekçi ve davulcu mânileri, 5. İstanbul'da bazı sokak satıcılarının mânileri, 6. İstanbul meydan kahvelerinin cinaslı mânileri, 7. Doğu Anadolu'da hikâye manileri, 8. Mektup mânileri (2015: 197-198) şeklinde kümelenmiştir. Ekşisözlük'te ise maniler üzerine şu başlıkların açıldığı görülür:

maniler, ekşisözlük mâni kapışması, mani dönemi, sallama aşk manileri, düğün davetiyelerindeki maniler, tiki manileri, bir kadının ă̆zından yazılmış maniler, hatıra defterine yazılmıs maniler, sünnet anileri, falım manileri, zütten uydurma maniler, hatıra defterine yazılmış maniler, ayar manileri, tez manileri, yazarlardan iki satırlık maniler, davulcu manileri, tarihi mani, Ramazan manileri, Girit manileri.

\section{Ekşisözlük’te türkü}

Ezgili bir sözlü tür olan ve mâni, hikâye ve fikra gibi sözlü türlerle ilişki içerisinde olan türküleri İlhan Başgöz "gerçekle hayali, sağ düşünce ile rüyayı, sözün ve ona koşulan sazın dili ile birleşen şiir (2008: 15)" şeklinde tanımlamıştır. Boratav ise 100 Soruda Türk Halk Edebiyatı adlı çalışmasında söylendikleri yerleri ve konularını esas alarak türküleri kümelemiştir: "1. Lirik türküler: Ninniler, aşk türküleri, gurbet türküleri, hapishane türküleri, ağıtlar, çeşitli başka duyguluk konular üzerine türküler./ 2. Taşlama, yergi, güldürü türküleri./ 3. 
Anlatı türküleri: Efsane konulu türküler, bölgelere ve bireylere özgü konuları olan türküler, tarihi konuları olan türküler./ 4. İş türküleri./ 5. Tören türküleri: Bayram türküleri, dügün türküleri, dinlik ve mezheplik törenlere değin türküler, ağıt törenlerinde söylenen türküler./ 6 . Oyun ve dans türküleri: Çocuk oyunlarında söylenenler, büyüklerin oyunlarında söylenenler (akt. Başgöz, 2008: 32-33).

Dijital ortam, her türlü özgün fikir ve tasarımların hızlıca yaygınlaşabildiği sanal platformdur. Kimliklerini "komik", "eğlenceli” patentini almak veya bu statüye erişmek isteyen özgün imge avcılarınca anonim türkülerin veya güncel şarkıların dijital ortamda yeniden çeşitli eşleştirmelerle ele alındığını; bunlarınsa videolar, fotoğraflar ve yorumlar paylaşan çeşitli sosyal ağlarda hızlıca yaygınlaştığı görülmektedir: Amanın MANGOyun meler gelir, haydi de MANGOyun meler gelir.../ Deniz kenarında BIEV yapmışlar.../ YVES ROCHER yolları dar, dar, bana bakma benim yârim var.../ BEYMEN benim gamlı yaslı gönlüme.../ AVVA çiçek açmış yaz mı gelecek.../ Yavri yavri PUMA kuşu yükseklerden seslenir.../ Pala RAMSEY derler onun namına vay vay.../ MACHKA yolları taşli, geliyor kara kaşli.../ Sarı saçlarını deli gönlüme, bağlamışım çözülmüyor LCW .../ Hamam tası gümüşten, yeni çıkmış HOTIÇten.../ Yaylalar yaylalar, yüküm şimşir kaşıktır, FLO FLO yaylalar.../ HATEMOĞLU derler benim aslıma.../ WATSONS bu dünya, bitsin bu rüya. Türküler ile ilgili çeşitli çeşitli bilgi paylaşımlarının bulunduğu ve sınıflandırmaların da yapıldığı Ekşisözlük’teki türkü başlıklarının şu şekilde olduğu görülmektedir:

türküler, tüyleri diken diken eden türküler, dinledikçe ömürden on yll götüren türküler, sözlükçülerin en sevdiği on türkü, yazarların sevdiği türküler, en iyi türküler, geceye bir türkü bırak, cinsel çağrışımlı türküler, az kişinin bildiği süper türküler, ăglatan türküler, ilk türküler, Kerkük türküleri, Anadolu türküleri, en güzel Ege türküsü, elektronik türküler, güne iyi başlata türküler, gece dinlenesi türküler, en damar türküler, sansürlenen türküler, sürrealist türküler, anonim argo türküler, cinsel çă̆rışımlı türküler, erotik çağrışımlı türküler, duygulu türküler, beyaz türküler, beraber ve solo türküler, Erzurum türküleri, Kırım türküleri, Malatya türküleri, türkü sevmeyen insan, uzun yol türküleri, yüreğe dokunan Karadeniz türküleri, doktora türküleri, eşklya türküleri, Balıkesir türküleri, Mordor türküleri, Istanbul türküleri, sevilen türkülerin en vurucu cümlesi.

\section{Sonuç}

Araştırmada bir dijital sözlükte katılımcı kitlelerce sözlü türlerin (özellikle eril bir dille) yeniden ele alındığı, güncellendiği ve işlendiği tespit edilmiştir. Kültürel belleğin oluşumunun yeni yüzü, geleneklerin sürekli güncellendiği yeni mekân ve yeni halk grubu ya da kimliklerin belirdiği farklı bir alan olan dijital ortamın aynı zamanda kültürbilimciler için yeni çalışma sahaları ve konuları oluşturduğu saptanmıştır. Dijital ortamda güncellenen gelenekler yeni ustalarını/tasarımcılarını çeşitli biçimlerde tasarlamakta ve tasarlamaya da devam etmektedir. Paylaşımın dayanılmaz hazzına ulaşan yeni nesil ustalar ise elektronik kültür ortamında yeni kitleler oluşturmakta, farklı gruplara dahil olabilme şansına sahip olmaktadırlar. Aynı zamanda sözlü geleneklerin elektronik kültür ortamı mahlası edinen ustalar eliyle çağın şartları ve yaşam tarzına bağlı olarak paylaşıldığı, derlendiği ve yeniden güncellendiği de görülmektedir. Hemen her türlü performansa açık dijital ortamın aynı zamanda yeni çeş- 
me başları, köy odaları, kıraathaneler, ritüel, şenlik ve festival alanları olduğu söylenebilir. Tüm bu alanlar aynı zamanda gönüllü olarak mahsulleri derleyen ve onları işleyen dijital ortam halkbilim ve kültürbilimcilerini de oluşturmuştur. Üniversite laboratuvarlarında bilimsel çalışmalar yapan profesyonel kültür araştırmacılarının hem bu kitle hem de derledikleri malzemeler üzerine daha fazla düşünmesi ve araştırma yapması gerekmektedir. Böylece Türk kültürünün genetik kodlarının oluşum aşamaları, geleneklerin ve sözlü türlerin yeni boyutları daha iyi anlaşılabilecek; toplumun ya da kültürün inşa aşamaları üzerine kuramlar ve metotlar geliştirme imkânı doğacaktır.

\section{Kaynaklar}

Acun, R. (2011). Her dem yeniden doğmak: Online sosyal ağlar ve kimlik, Millî Folklor. S. 89. ss. 66-77.

Başgöz, İ. (2006). Atasözleri hakkında atasözleri ya da atasözlerinin toplumsal anlamı, (N. T. Toçoğlu, Çev.) Millî Folklor. S. 70, ss. 85-91.

Boratav, P. N. (2015). 100 soruda Türk halk edebiyatı. Ankara: Bilgesu.

Çobanoğlu, Ö. (2000). Aş̧ı tarzı kültür geleneği ve destan türü. Ankara: Akçağ.

Çobanoğlu, Ö. (2004). Türk dünyası ortak atasözleri sözlüğü. Ankara: Arma.

Çobanoğlu, Ö. (2005). Halkbilimi kuramları ve araştırma yöntemleri tarihine giriş. Ankara: Akçağ.

Ergin, M. (1992). Orhun abideleri. İstanbul: Boğaziçi.

Ergin, M. (2011). Dede Korkut kitabı - I. Ankara: Türk Dil Kurumu.

Freud, S. (2014). Grup psikolojisi ve ego analizi, (B. Yücel, Çev.) Ankara: Alter.

Goody, J. (2009). Sözlü kültür. Millî Folklor. S. 83. ss. 128-132.

Gülçayır, S. (2008). Kuşaktan foruma geçiş ve bilgisayar atasözleri. Millî Folklor. S. 79. ss. 70-77.

Gürel, E. -Yakın, M. (2007). Ekşi Sözlük: Postmodern elektronik kültür. Selçuk Üniversitesi İletişim Fakültesi Akademik Dergisi, 4. cilt, S. 4. Konya.

Kırcı Uğurlu, E. (2014). Kültürel bellek aktarıcısı olarak ninni. Millî Folklor. S. 102. ss. 43-52.

Oğuz, M. Ö. vd. (2005). Türk halk edebiyatı el kitabı. Ankara: Grafiker.

Oğuz, M. Ö. vd. (2014). Halkbiliminde kuramlar ve yaklaşımlar I. Ankara: Geleneksel.

Ong, W. J. (2010). Sözlü ve yazılı kültür sözün teknolojileşmesi. (S. Postacıŏlu Banon, Çev. ) İstanbul: Metis.

Özdemir, N. (2005). Cumhuriyet dönemi Türk eğlence kültürü. Ankara: Akçağ.

Özdemir, N. (2008a). Medya kültür ve edebiyat. Ankara: Geleneksel.

Özdemir, N. (2008b). Kültürel ekonomik imge olarak Nasreddin Hoca. Millî Folklor. S. 77. ss. 11-20.

Yıldırım, D. (2016). Türk edebiyatında Bektaşi fikraları. Ankara: Akçağ.

\section{Elektronik kaynaklar}

http://www.tdk.gov.tr/index.php?option=com_gts\&kelime=DEYİM ,erişim tarihi:23.04.2019.

https://eksisozluk.com/fender-vs-gibson--2136114, erişim tarihi:11.03.2019.

http://www.zaytung.com, erişim tarihi:17.03.2019. 